\title{
Data report: preliminary investigation of carbonate- cemented zones in IODP cores from Canterbury Basin, South Island, New Zealand ${ }^{1}$
}

\author{
David Carson $^{2}$ and Kathleen M. Marsaglia²
}

\begin{abstract}
Chapter contents

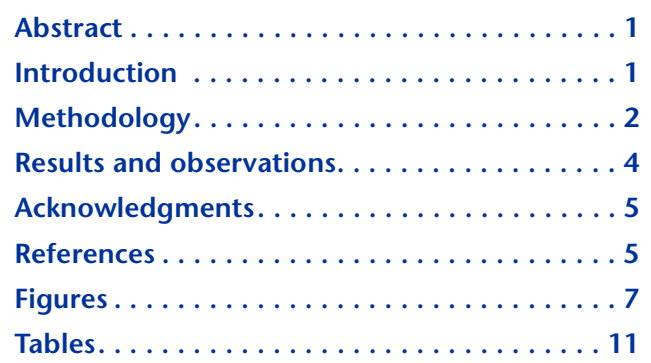

${ }^{1}$ Carson, D., and Marsaglia, K.M., 2015. Data report: preliminary investigation of carbonatecemented zones in IODP cores from Canterbury Basin, South Island, New Zealand. In Fulthorpe, C.S., Hoyanagi, K., Blum, P., and the Expedition 317 Scientists, Proc. IODP, 317: Tokyo (Integrated Ocean Drilling Program Management International, Inc.). doi:10.2204/iodp.proc.317.204.2015 ${ }^{2}$ Department of Geological Sciences, California State University, 18111 Nordhoff Street, Northridge CA 91330-8266, USA. Correspondence author: DCarson@getty.edu

\begin{abstract}
A selection of 30 indurated (cemented) sediment samples from Integrated Ocean Drilling Program Expedition 317 sites were examined using various techniques to assess the nature and chemistry of authigenic carbonate cements. Flatbed scanning of thin sections coupled with optical microscopy and scanning electron microscope/energy dispersive X-ray (SEM/EDS) mapping provides a visual reference catalog that is presented here as supplementary material. These techniques, along with X-ray diffraction, were used to confirm the presence of calcite cement in 24 of the 30 samples, with the remaining 6 samples having either dolomite or magnesian calcite cement. Carbon and oxygen isotopic analysis was performed on a subset of samples to provide additional information regarding the nature of the cements. Proportions of terrigenous and bioclastic components, matrix, cement, and porosity were estimated by point-counting thin sections.
\end{abstract}

\section{Introduction}

In order to accurately reconstruct sea level history and subsequent depositional environments, it is necessary to test these sea level models against data from the geologic record. The occurrence of carbonate cements provides a method of understanding sea level history and the record of exposure because authigenic carbonate precipitation occurs in a wide range of conditions from marine to nonmarine. Outcrop studies would normally be used to study stratigraphy; however, these studies are difficult to employ with carbonate cements because of overprinting by burial and subaerial diagenesis. In order to obtain samples that have not been overprinted by later diagenetic events, material cored from modern shelf areas is necessary. Only a few shallow-shelf coring expeditions were carried out during the Deep Sea Drilling Project (DSDP), Ocean Drilling Program (ODP), and Integrated Ocean Drilling Program (IODP), and only one addressed the cementation history of siliciclastic shelf sediments. That study focused on the New Jersey shelf (Malone et al., 2002).

Recent drilling during IODP Expedition 317 on the Canterbury shelf provided important core records of shelf strata with local carbonate-cemented zones that may relate to seismic reflectors, including sequence boundaries (see the "Expedition 317 summary" chapter [Expedition 317 Scientists, 2011]). The purpose of 
this study is to further characterize the texture and chemical composition of the most indurated zones in the carbonate-cemented intervals in Expedition 317 cores. Understanding the conditions under which these zones formed is critical to enabling a more detailed interpretation of the seismic sequence stratigraphy of the Canterbury shelf and will contribute to additional testing of sea level models (Lu et al., 2005).

\section{Geologic setting and Expedition 317 background}

The Canterbury Basin is located on a passive margin that developed along the eastern portion of the South Island of New Zealand, which is a part of a continental fragment, the New Zealand Plateau, that rifted from Antarctica starting at $\sim 80 \mathrm{Ma}$ (Fulthorpe et al.,1996; Carter, 1998; Lu et al., 2005; see the "Expedition 317 summary" chapter [Expedition 317 Scientists, 2011]). The basin lies at the landward edge of the continental fragment and underlies the present-day onshore Canterbury plains and offshore continental shelf. The depositional history of the Canterbury Basin is a tectonically controlled transgressive-regressive cycle. The Cretaceous to Oligocene was a period of general transgression caused by relative sea level rise accompanied by postrift subsidence. Sequence boundaries suggest that the trend of sea level rise was punctuated by periods of sea level lowering or stillstand. In the Miocene, a regressive phase was initiated in response to increasing sediment supply that began with the mid-Cenozoic development of strike-slip motion along the boundary of the Pacific and Australian plates, the Alpine fault. Regression increased as the amount of convergence at the boundary increased. Convergence along this fault initiated the uplift of the Southern Alps around $8 \mathrm{Ma}$.

During Expedition 317 In 2009, four sites were cored in the Canterbury Basin at three sites on the continental shelf (Sites U1353, U1354, and U1351, landward to basinward) and one site (U1352) on the continental slope in water depths ranging from 85 to $344 \mathrm{~m}$ (Fig. F1) (see the "Expedition 317 summary" chapter [Expedition 317 Scientists, 2011]).

Drilling was performed using the advanced piston corer (APC), extended core barrel (XCB), and rotary core barrel (RCB) systems. Three holes were drilled at each of the three continental shelf sites (Sites U1351, U1353, and U1354), and material was recovered from the upper Miocene to the recent (Fig. F2). Drilling initiated at Site U1351 located on the outer shelf at a position thought to be near the historic low- stand shoreline (see the "Expedition 317 summary" chapter [Expedition 317 Scientists, 2011]). This would have placed Sites U1353 and U1354 onshore during the same lowstand. Four holes were drilled at Site U1352, on the upper continental slope, and the recovered cores represent a complete section from modern slope sediment down to Eocene limestone. Site U1352 was the deepest hole drilled in a single expedition and the second deepest hole in the history of scientific ocean drilling.

\section{Methodology}

Indurated intervals of Expedition 317 cores were sampled shipboard for use in this study. Thirty sample billets thought to contain carbonate cements were selected for analysis from the indurated intervals and split with a saw at California State University Northridge (CSUN; USA). A portion of each billet was impregnated with blue-dyed epoxy, and then a thin section was prepared to a $30 \mu \mathrm{m}$ thickness and polished, prepared without the traditional coverslip to facilitate chemical analysis via scanning electron microscope (SEM). A second portion weighing $\sim 2 \mathrm{~g}$ was cleaved off of the remaining sample using a hand-screwed steel guillotine and ground to a fine powder using an agate mortar and pestle. The resulting powder was split to be analyzed by powder X-ray diffraction (XRD) and isotopic analysis. Table T1 lists the location and depth for each sample along with the analysis techniques employed for each.

\section{Thin section imaging and point counts}

Documentation of the macro texture of each sample was achieved by imaging the entire thin section on a standard flatbed scanner. The thin sections were scanned in transmitted light at a resolution of 3200 dots per inch, which resulted in a final image with dimensions of 3366 pixels wide $\times 5605$ pixels high . In addition, the microtexture of each sample was documented using polarized light microscopy (visible transmitted light, with and without polarizing filters). These images assisted in describing the overall character of the samples in terms of components, matrix, porosity, and cement content (see COREIMAGES in "Supplementary material"). Estimations of pore size and abundance of bioclastic material were made using percentage diagrams (Table T2). More detailed compositional analysis was provided through point-counting the 30 thin sections using a Leitz Labrolux 12 Pol petrographic microscope fitted with an automated stage and counter. Three-hundred points were counted per section, and counted 
categories included various sand, matrix, cement and, porosity (Table T3).

\section{X-ray diffraction analysis}

XRD was carried out at the Getty Conservation Institute in Los Angeles, California (USA) using a Siemens D5005 diffractometer. Approximately $200 \mathrm{mg}$ of finely ground sample was placed on a zero-background quartz plate and flattened to an approximate uniform thickness. Scans were performed using the following conditions within the Bruker XRD Commander software: locked coupled scan, $40 \mathrm{kV}, 30 \mathrm{~mA}$, scan from $10^{\circ}$ to $60^{\circ} 2 \theta$, step size $0.01^{\circ} 2 \theta$, and scan speed of $1 \mathrm{~s} /$ step. The resulting raw files were imported into the Bruker DiffracPlus software package and transformed using a fourier noise filter. Mineral peak identification was confirmed using an embedded JCP2 PDF database file. Slight differences in the thickness of the individual powdered samples were noted as a shift in the position of the optimal quartz peak position at $26.66^{\circ} 2 \theta$ and were corrected by adjusting the X-offset of each pattern. The diffraction peak position and relative intensity, measured as counts per second for quartz and the identified carbonate minerals (calcite, $\mathrm{Mg}$ calcite, and dolomite), were then calculated using the DiffracPlus software (Table T4). Methodology for determining quantitative percentages of components was not available with this software package and are not reported here.

\section{Scanning electron microscopy}

Backscattered electron (BSE) imaging and energy dispersive X-ray spectroscopy (EDS) mapping were performed on all 30 thin section samples to obtain elemental composition and distribution of the cements within the samples (see COREIMAGES in "Supplementary material"; Table T5). The analysis was carried out at the Getty Conservation Institute on a Philips-FEI XL30 environmental scanning electron microscope with field emission gun (ESEM-FEG). The samples were imaged uncoated with a chamber pressure of 0.8 torr, beam voltage of $20 \mathrm{keV}$, and spot size of 3. X-ray EDS mapping was performed with an Oxford X-Max $80 \mathrm{~mm}^{2}$ detector and collected and processed with the Oxford INCA software package. To better facilitate the comparison of cemented zones within the samples, area spectra of these zones were reconstructed from the elemental map data set within the INCA software. Three separate areas representing the cemented zone were selected in each map. The three resulting spectra were manually evaluated for maximum peak height in counts, divided by the accumulation time, and averaged yielding a value in counts per second.

Tabulated results of elemental analysis performed on samples that are imaged uncoated while in low-vacuum mode of an environmental SEM need to be carefully considered because of the physics of the beam interaction with the sample. Numerical results are generally considered to be qualitative because of deflection of the electron beam as it passes through water vapor in the chamber, which can lead to X-ray signal generated from outside of the region of interest. Relative peak intensities and peak ratios are usually more informative, such as the $\mathrm{Ca} / \mathrm{Mg}$ ratio, which when combined with XRD data can confirm mineral identification.

\section{Isotopic analysis}

Previous studies have shown that using $\delta^{13} \mathrm{C}$ and $\delta^{18} \mathrm{O}$ values can aid in determining the origin (i.e., marine, brackish, or freshwater) of authigenic carbonate cements (Malone et al., 2002). The 30 study samples were evaluated using optical microscopy and SEM imaging to determine their suitability for isotopic study. Only samples with minimal evidence of bioclastic carbonate fragments were submitted for isotopic analysis. This resulted in 15 of the original 30 samples being submitted to California State University, Long Beach, for analysis of the gas isotope ratios of ${ }^{13} \mathrm{C} /{ }^{12} \mathrm{C}$ and ${ }^{18} \mathrm{O} /{ }^{16} \mathrm{O}$. Sample analysis was carried out using a Thermo-Finnigan Gas Bench II online gas preparation and introduction system coupled with a Finnigan DELTAplus XP stable isotope mass spectrometer. Approximately $200 \mu \mathrm{g}$ of each sample, as well as three different standards (NBS-18, NBS-19, and in-house Standard A), were placed in individual sample vials and heated to $72^{\circ} \mathrm{C}$. The headspace of each vial was flushed with helium for $5 \mathrm{~min}$, followed by automated dropwise addition of concentrated phosphoric acid. The samples were then allowed to react for a minimum of $2 \mathrm{~h}$ for the evolved $\mathrm{CO}_{2}$ gas to reach equilibration within the vial. Measurement of the ${ }^{13} \mathrm{C} /{ }^{12} \mathrm{C}$ and ${ }^{18} \mathrm{O} /{ }^{16} \mathrm{O}$ ratios was then performed sequentially for each standard and sample, during which 10 doses of each were evaluated. Generated peaks were evaluated for their consistent peak height and shape, and values deemed to be nonrepresentative were rejected. The resulting $\delta^{13} \mathrm{C}$ and $\delta^{18} \mathrm{O}$ values were then corrected for linearity and converted to their relative Peedee belemnite (PDB) values using a calibration curve created from the three standards. These results are presented in Table T6. 


\section{Results and observations}

\section{Lithologies}

Imaging data for each sample including core photo, thin section scan, optical microscopy (plane and polarized light), SEM-BSE, and X-ray elemental maps were combined into one document to provide a visual reference that highlights sample features at different magnification scales (see COREIMAGES in "Supplementary material").

The results of general observations and more detailed point counting of grains for each of the samples is presented in Tables T2 and T3. The lithology naming scheme for the samples follows the method adopted by Expedition 317 scientists, which was modified from the "Expedition 317 summary" chapter (Expedition 317 Scientists, 2011). The samples were separated into three categories: limestone, marlstone, and sandy marlstone. Four samples (from Cores 317-U1351B-12H, 19X, and 96X and 317U1354C-20X) were found to contain primarily bioclastic material. In contrast, samples from Cores 317U1352B-2H, 317-U1352C-10R, 317-U1353B-88X and $92 \mathrm{X}$, and $371-\mathrm{U} 1352 \mathrm{~B}-13 \mathrm{H}$ were found to contain primarily siliciclastic sand. The remaining samples showed mixed content, with variable bioclastic/sand ratios.

Grain sizes are relatively uniform across all samples, on the order of $<100 \mu \mathrm{m}$ for the siliciclastic particles. These particles are generally poorly to moderately sorted. Grain-to-grain contacts range from point to floating, and grain shapes range from angular to subangular. Dominant terrigenous sand constituents are quartz, feldspar, and mica, and these total up to $87 \%$ of the sample. Bioclasts range up to $\sim 40 \%$ of the sample and are mainly foraminifers and mollusk fragments. Other carbonate components include calcareous micritic matrix (calcareous biogenic silt to authigenic cement?) and fine pore-filling cement ranging up to $\sim 60 \%$ of the sample in fine micritic concretions.

The samples exhibit three main types of porosity: interparticle, intraparticle, and moldic. Porosity values were first estimated using area percentage charts ranging from $<1 \%$ to $30 \%$ for the sample set (Table T2). Point count results of porosity values were generally lower than those obtained using the estimation charts and range from $<1 \%$ to $22 \%$. Samples with the highest porosity contain the highest percentage of bioclasts. No significant correlation exists between the remaining point count data and the elemental, carbonate XRD, or isotope data.

\section{XRD and SEM}

The elemental composition of the cement and aggregate components were examined in thin section using low-vacuum SEM-EDS mapping. The elemental maps are located in COREIMAGES in "Supplementary material," whereas tabulated values in counts per second are provided for the cement in each sample and selected rhombohedral crystals in Table T5.

Results of XRD analyses are summarized in Table T4 and are presented as counts per second for quartz and the carbonate phases that were detected. This was done to simplify the data set, as the main focus of this research is on cement identification.

All of the elemental maps contain calcium as a significant element, and bulk XRD analysis confirmed the presence of calcite at some level in all of the samples. Multiple samples (from Cores 317-U1352B-2H, 317-U1352C-10R, 317-U1353B-88X and 92X, 317U1354A-15H, and 317-U1354B-13H) were found to contain magnesium as a major component of the cement correlated with calcium suggestive of magnesium-enriched phases such as dolomite or magnesian calcite. Evaluating the ratio of $\mathrm{Ca} / \mathrm{Mg}$ signal within the elemental maps in counts per second from reconstructed spectra of the cemented zones separates these samples into two groups. Samples from Cores 317-U1352B-2H and 10R, U1354A-15H, and $\mathrm{U} 1354 \mathrm{~B}-13 \mathrm{H}$ have ratios ranging from 1.4 to 2.0 . $\mathrm{XRD}$ analysis identified these samples as containing ferroan dolomite. Samples from Cores 317-U1353B$88 \mathrm{X}$ and $92 \mathrm{X}$, which have ratios of 7.3 and 10.1, respectively, were shown to contain magnesian calcite via $\mathrm{XRD}$. This link between $\mathrm{Ca} / \mathrm{Mg}$ ratio and verified mineralogic phase provides a way to identify the location of these phases within samples where they occur in minor amounts. Samples such as those from Cores 317-U1352B-52X and 317-U1352C-15R and $21 \mathrm{R}$, which show small crystals containing magnesium and calcium, can be evaluated. In all three cases, reconstructed spectra of the crystals show that the $\mathrm{Ca} / \mathrm{Mg}$ ratio falls in the same range as ferroan dolomite. A closer look at the XRD data table reveals that there are counts related to the ferroan dolomite peak for each of these samples.

Exceptions to these nice-fitting correlations exist. Sample 317-U1351B-46X-CC, 1-5 cm, shows 41 counts per second for ferroan dolomite, yet looking at the elemental maps, no correlation exists between the magnesium and calcium maps. This might be due to the fact that sample locations for thin section and XRD samples differ slightly. 
Very minor $(<1 \%)$ pyrite crystals were found in all 30 samples, noted by their characteristic high contrast in the BSE images and their morphological structure and confirmed through the correlation of Fe and $S$ intensities in EDS maps; a group of pyrite crystals can be seen in Figure F3. Other minerals observed by optical microscopy, such as micas, feldspars, and quartz, were also easily observed using the SEM-EDS maps and their characteristic structural features. For example, a particle of mica interleaved with pyrite can be observed in the lower left corner (see Fig. AF9 in COREIMAGES in "Supplementary material"), where magnesium, aluminum, and iron are all present in a single grain and the characteristic lamellae of the mica can be observed in the BSE image (part A).

\section{Isotopes}

The isotopic data are presented as a bivariate plot of $\delta^{18} \mathrm{O}$ PDB (\%o) vs. $\delta^{13} \mathrm{C}$ PDB (\%o) in Figure F4 with various grouping overlays including (A) arbitrary grouping by clustering; (B) categories of depositional environments as modified from Nelson and Smith (1996) following the work of Hudson (1977), Bathurst (1981), Choquette and James (1987), Moore (1989), Morse and Mackenzie (1990), and Marsaglia and Carozzi (1990); (C) mineral classification from Mozley and Burns (1993); and (D) color coded with XRD identification. The results cluster into four distinct groupings (labeled A-D). Groups A and $\mathrm{B}$ have relatively similar $\delta^{13} \mathrm{C}$ values and could potentially be grouped together; however, there is a large enough gap between the $\delta^{18} \mathrm{O}$ values that two separate groups were assigned. Group A consists of three samples with $\delta^{13} \mathrm{C}$ values ranging from $-2.3 \%$ to $-3.5 \%$ and $\delta_{18} \mathrm{O}$ values ranging from $-2.0 \%$ to $-2.4 \%$ and falls into a warm-water skeleton classification. Group B consists of six samples with $\delta^{13} \mathrm{C}$ values ranging from $-1.2 \%$ to $-3.9 \%$ and $\delta^{18} \mathrm{O}$ values ranging from $-0.1 \%$ o to $1.4 \%$. Using the Nelson classification scheme, these materials are derived from oozes (note that the relative percentage of calcareous components in these ooze samples is not specified).

The remaining two groups diverge significantly from the $\delta^{13} \mathrm{C}$ values that are observed in Groups A and B. Group C contains three samples (317-U1352B-2H, 317-U1354A-15H, and 317-U1354B-13H) that have $\delta^{13} \mathrm{C}$ values between $-12 \%$ and $-24 \%$ and $\delta^{18} \mathrm{O}$ values between $1.9 \%$ and $5.6 \%$. All three samples were identified as containing ferroan dolomite by XRD. The closest corresponding category in the Nelson and Smith identification scheme on the bivariate plot would be for mixing zone dolomites.

Group D contains two samples (317-U1353B-88X and $92 \mathrm{X}$ ) that have $\delta^{13} \mathrm{C}$ values below $-40 \%$; these two samples stem from the same drill site and were identified by XRD as containing magnesian calcite (see above). The extremely low $\delta^{13} \mathrm{C}$ values comfortably place these samples as being derived from a methanogenic origin. Having such low $\delta^{13} \mathrm{C}$ values is unusual but not unheard of for the region. Lawrence (1991) reported $\delta^{13} \mathrm{C}$ values below -30\%o PDB in concretionary dolomite deposits in Eastern Marlborough, New Zealand, on the South Island. Sample 317-U1354C-17X-CC, $3 \mathrm{~cm}$, was originally assigned to Group C; however, it is known to contain mainly calcite from XRD and SEM analysis and could potentially also be assigned to Group B. It appears that the isotopic values could be transitional between the two groups or this may represent sampling of a dolomite-rich zone of the sample billet.

\section{Acknowledgments}

This study was made possible though postcruise funding to Marsaglia from the Consortium for Ocean Leadership. Samples and/or data were provided by the Integrated Ocean Drilling Program (IODP). We thank the Getty Conservation Institute for access to their labs and instrumentation and Cedric John, Ken Miller, and Peter Blum for their detailed reviews.

\section{References}

Bathurst, R.G.C., 1981. Early diagenesis of carbonate sediments. In Parker, A., and Sellwood, B.W. (Eds.), Sediment Diagenesis. NATO Sci. Ser., Ser. C, 115:349-377. doi:10.1007/978-94-009-7259-9_7

Carter, R.M., 1998. Two models: global sea-level change and sequence stratigraphic architecture: Sediment. Geol., 122(1-4):23-26. doi:10.1016/S0037-0738(98)00111-0

Choquette, P.W., and James, N.P., 1987. Diagenesis of limestones, 3. The deep burial environment. Geosci. Can., 14(1):3-35. http://journals.hil.unb.ca/index.php/ GC/article/view/3482/3996

Expedition 317 Scientists, 2011. Expedition 317 summary. In Fulthorpe, C.S., Hoyanagi, K., Blum, P., and the Expedition 317 Scientists, Proc. IODP, 317: Tokyo (Integrated Ocean Drilling Program Management International, Inc.). doi:10.2204/iodp.proc.317.101.2011

Fulthorpe, C.S., Carter, R.M., Miller, K.G., and Wilson, J., 1996. Marshall paraconformity: a mid-Oligocene record of inception of the Antarctic Circumpolar Current and 
coeval glacio-eustatic lowstand? Mar. Pet. Geol., 13(1):61-77. doi:10.1016/0264-8172(95)00033-X

Hudson, J.D., 1977. Stable isotopes and limestone lithification. J. Geol. Soc. (London, U. K.), 133:637-660. doi:10.1144/gsjgs.133.6.0637

Lawrence, M.J.F., 1991. Early diagenetic dolomite concretions in the Late Cretaceous Herring Formation, eastern Marlborough, New Zealand. Sediment. Geol., 75(12):125-140. doi:10.1016/0037-0738(91)90054-H

Lu, H., Fulthorpe, C.S., Mann, P., and Kominz, M.A., 2005. Miocene-Recent tectonic and climatic controls on sediment supply and sequence stratigraphy: Canterbury basin, New Zealand. Basin Res., 17(2):311-328. doi:10.1111/j.1365-2117.2005.00266.x

Malone, M.J., Claypool, G., Martin, J.B., and Dickens, G.R., 2002. Variable methane fluxes in shallow marine systems over geologic time: the composition and origin of pore waters and authigenic carbonates on the New Jersey shelf. Mar. Geol., 189(3-4):175-196. doi:10.1016/ S0025-3227(02)00474-7

Marsaglia, K.M., and Carozzi, A.V., 1990. Depositional environment, sand provenance, and diagenesis of the Basal Salina Formation (lower Eocene), northwestern
Peru. J. South Am. Earth Sci., 3(4):253-267. doi:10.1016/ 0895-9811(90)90007-N

Moore, C.H. (Ed.), 1989. Carbonate Diagenesis and Porosity. Dev. Sedimentol., 46. doi:10.1016/S00704571(08)71054-9

Morse, J.W., and Mackenzie, F.T., 1990. Geochemistry of Sedimentary Carbonates: Amsterdam (Elsevier). doi:10.1016/S0070-4571(08)70329-7

Mozley, P.S., and Burns, S.J., 1993. Oxygen and carbon isotopic composition of marine carbonate concretions: an overview. J. Sediment. Petrol., 63(1):73-83. doi:10.1306/ D4267A91-2B26-11D7-8648000102C1865D

Nelson, C.S., and Smith, A.M., 1996. Stable oxygen and carbon isotope compositional fields for skeletal and diagenetic components in New Zealand Cenozoic nontropical carbonate sediments and limestones: a synthesis and review. N. Z. J. Geol. Geophys., 39(1):93-107. doi:10.1080/00288306.1996.9514697

Initial receipt: 5 September 2012

Acceptance: 29 January 2015

Publication: 22 May 2015

MS 317-204 
Figure F1. Locations of Expedition 317 drill sites in the Canterbury Basin. Sites U1353, U1354, and U1351 are located on the continental shelf, and Site U1352 is located on the continental slope (from Expedition 317 Scientists, 2011).

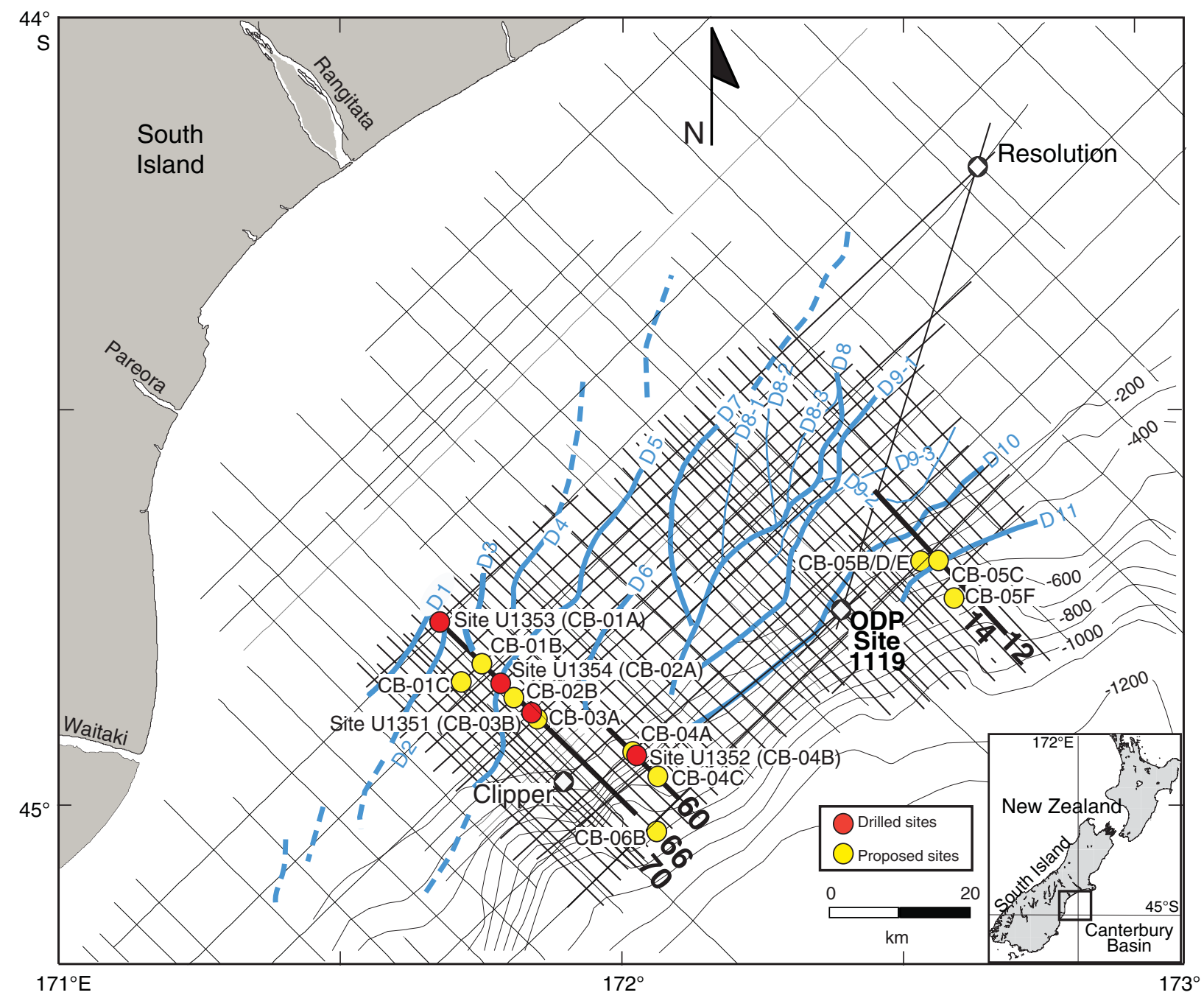


Figure F2. Summary of lithology and unit boundaries (modified from Expedition 317 Scientists, 2011). Blue triangles $=$ locations of shipboard thin sections (lithified core samples) examined, red triangles $=$ locations of thin sections newly produced during this study.

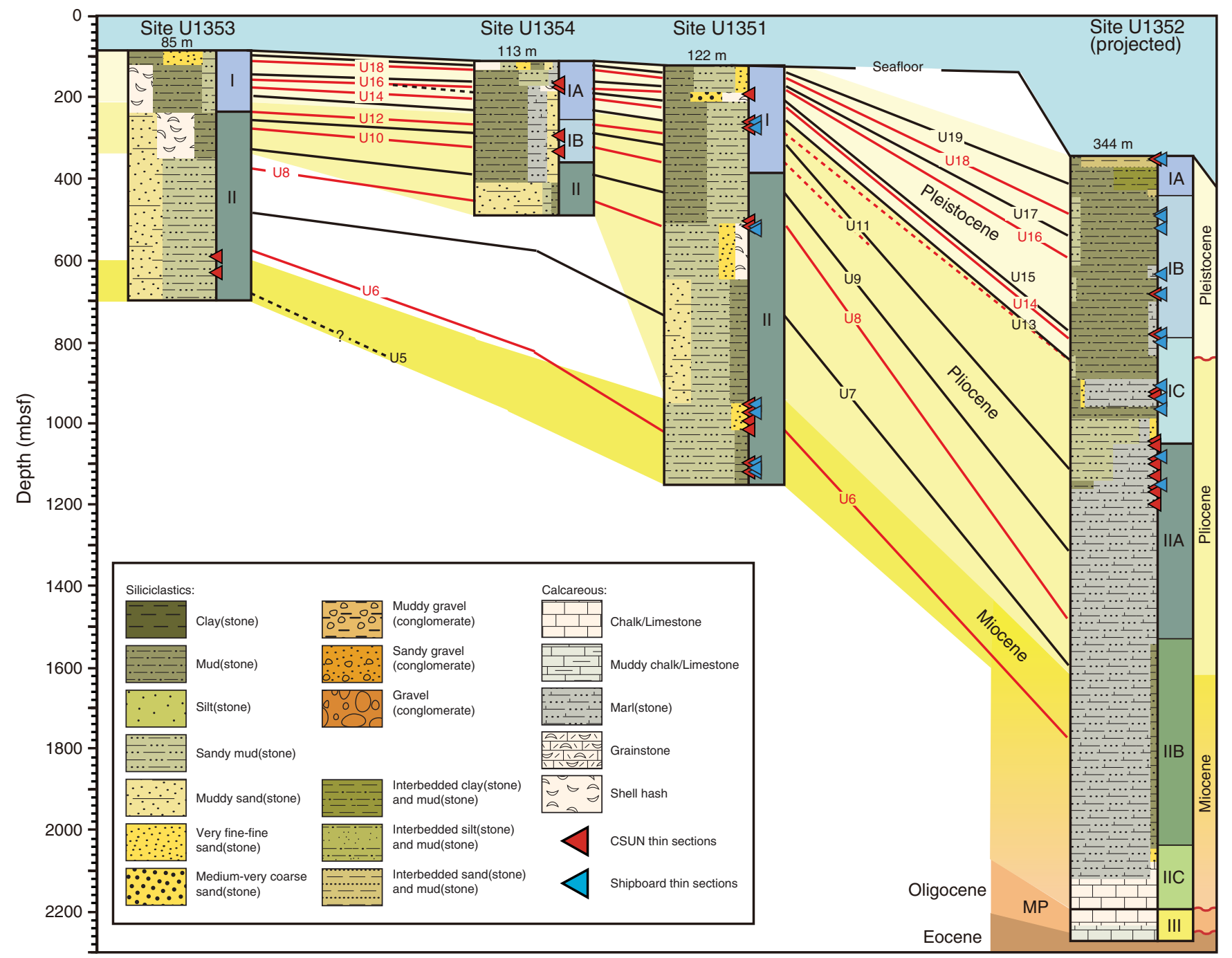


Figure F3. Backscattered electron (BSE) micrograph of fractured section for Sample 317-U1352C-10R-1W, 50 $\mathrm{cm}$. White arrows $=$ two of the numerous dolomite rhombohedral crystals in the sample. The shape of the crystals and isolated nature indicate that they grew within the pore space of the sample. Circle $=$ high contrast pyrite cluster.

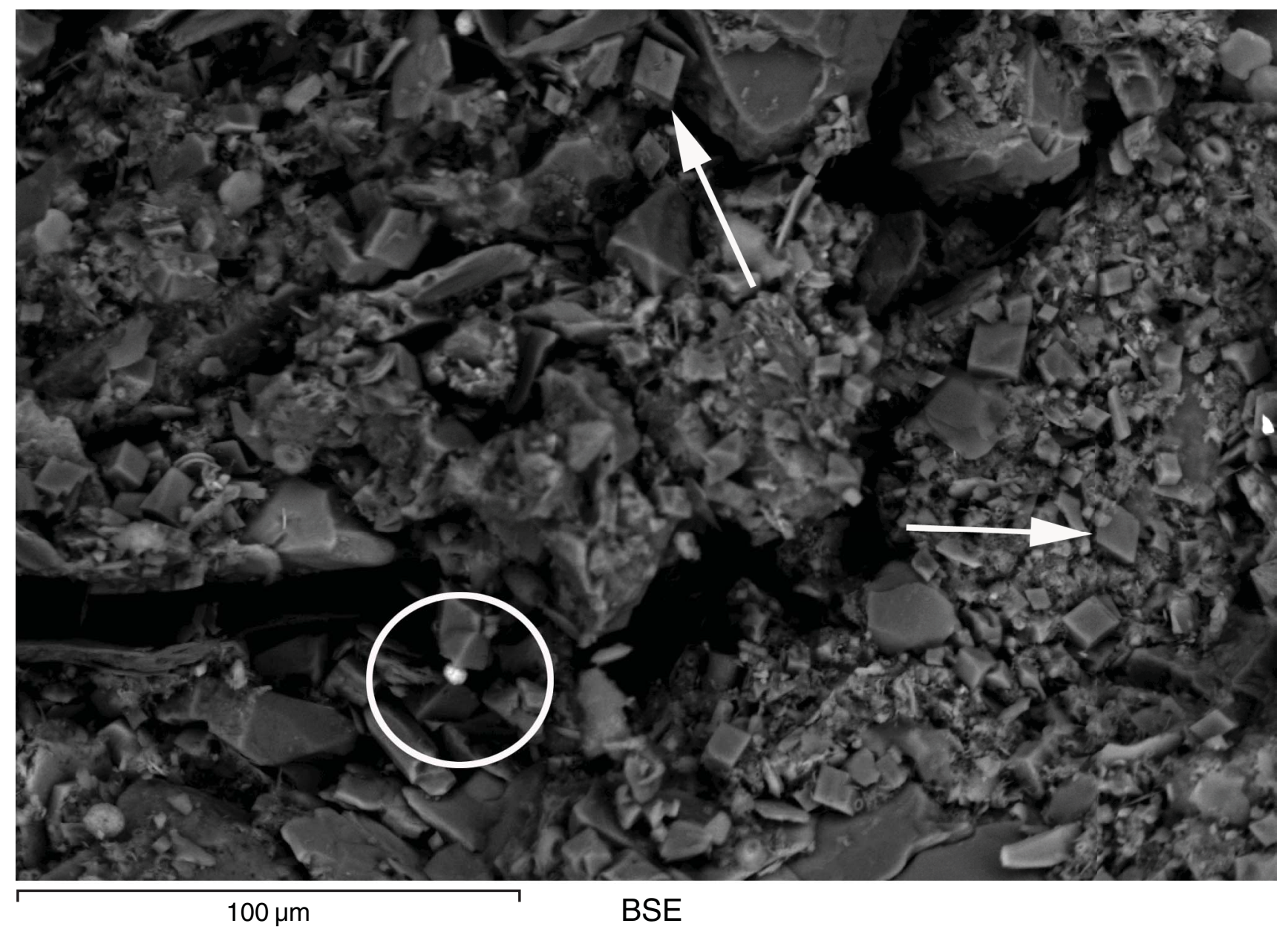


Figure F4. Isotopic data. A. Arbitrary grouping based on clustering. B. Plot with literature values as modified from Nelson et al. (1996). C. Plot with literature values from Mozley and Burns (1993). D. Plot based on phase identification from XRD. Blue $=$ calcite, red $=$ dolomite, green $=\mathrm{Mg}$ calcite .

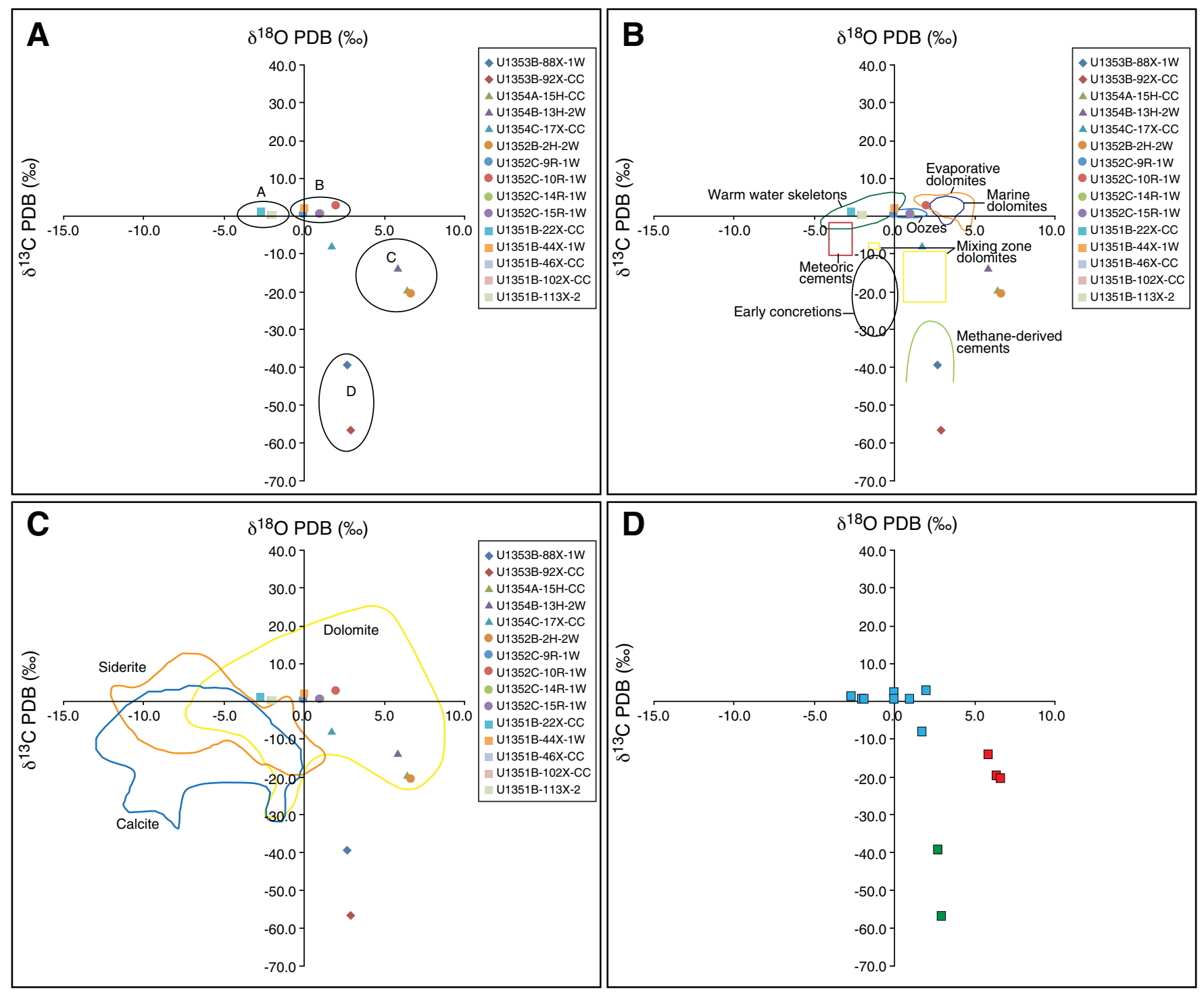


Table T1. Sample identification and analysis checklist.

\begin{tabular}{|c|c|c|c|c|c|c|c|c|c|c|c|}
\hline Hole & Core & Section & $\begin{array}{l}\text { Interval } \\
(\mathrm{cm})\end{array}$ & $\begin{array}{l}\text { Depth } \\
\text { DSF }(m)\end{array}$ & $\begin{array}{l}\text { Thin } \\
\text { section } \\
\text { scan }\end{array}$ & $\begin{array}{l}\text { Core } \\
\text { photo }\end{array}$ & $\begin{array}{l}\text { Point } \\
\text { count }\end{array}$ & SEM & EDS & XRD & $\begin{array}{c}\text { Isotope } \\
\text { ratio }\end{array}$ \\
\hline \multicolumn{12}{|l|}{ 317- } \\
\hline U1351B & $12 \mathrm{H}$ & $1 \mathrm{~W}$ & 115-116 & 75.7 & $\mathrm{X}$ & $\mathrm{X}$ & $\mathrm{X}$ & $\mathrm{X}$ & $\mathrm{x}$ & $\mathrm{X}$ & \\
\hline U1351B & $19 x$ & CC & $25-27$ & 141.6 & $\mathrm{x}$ & $\mathrm{x}$ & $\mathrm{x}$ & $\mathrm{x}$ & & $x$ & \\
\hline U1351B & $22 x$ & CC & $10-12$ & 170.4 & $\mathrm{x}$ & $\mathrm{x}$ & $x$ & $\mathrm{x}$ & $\mathrm{x}$ & $\mathrm{x}$ & $\mathrm{x}$ \\
\hline U1351B & $44 X$ & $1 \mathrm{~W}$ & $3-8$ & 381.1 & $\mathrm{x}$ & $x$ & $\mathrm{x}$ & $\mathrm{x}$ & $\mathrm{x}$ & $\mathrm{x}$ & $\mathrm{x}$ \\
\hline U1351B & $46 X$ & $\mathrm{CC}$ & $1-5$ & 400.2 & $\mathrm{X}$ & $\mathrm{X}$ & $\mathrm{x}$ & $\mathrm{x}$ & $\mathrm{x}$ & $\mathrm{x}$ & $\mathrm{X}^{*}$ \\
\hline U1351B & $96 \mathrm{X}$ & CC & $5-8$ & 831.8 & $\mathrm{x}$ & $\mathrm{X}$ & $\mathrm{x}$ & $\mathrm{x}$ & & $\mathrm{x}$ & \\
\hline U1351B & $98 \mathrm{X}$ & CC & $30-34$ & 851.0 & $\mathrm{x}$ & $\mathrm{x}$ & $\mathrm{x}$ & $\mathrm{x}$ & $\mathrm{x}$ & & \\
\hline U1351B & $100 x$ & 3 & $15-17$ & 870.3 & $\mathrm{x}$ & $\mathrm{x}$ & $\mathrm{x}$ & $\mathrm{x}$ & $\mathrm{x}$ & $x$ & \\
\hline U1351B & $102 x$ & CC & $4-8$ & 889.6 & $\mathrm{x}$ & $\mathrm{x}$ & $\mathrm{x}$ & $x$ & $x$ & $x$ & $\mathrm{X}$ \\
\hline U1351B & $111 x$ & 1 & $4-7$ & 975.9 & $\mathrm{x}$ & $\mathrm{x}$ & $\mathrm{x}$ & $x$ & $x$ & $\mathrm{x}$ & \\
\hline U1351B & $113 \mathrm{X}$ & 2 & 131-135 & 995.1 & $\mathrm{x}$ & $\mathrm{x}$ & $\mathrm{x}$ & $\mathrm{x}$ & $\mathrm{x}$ & $\mathrm{x}$ & $\mathrm{x}$ \\
\hline U1352B & $2 \mathrm{H}$ & $2 \mathrm{~W}$ & 32 & 8.2 & $\mathrm{x}$ & $\mathrm{X}$ & $\mathrm{x}$ & $\mathrm{x}$ & $\mathrm{x}$ & $\mathrm{x}$ & $\mathrm{X}$ \\
\hline U1352B & $42 x$ & $5 \mathrm{~W}$ & 5 & 341.1 & $X$ & $\mathrm{x}$ & $\mathrm{X}$ & $\mathrm{x}$ & $\mathrm{x}$ & $\mathrm{x}$ & \\
\hline U1352B & $52 x$ & $7 \mathrm{~W}$ & 4 & 437.1 & $\mathrm{x}$ & $\mathrm{x}$ & $\mathrm{x}$ & $\mathrm{x}$ & $\mathrm{x}$ & $\mathrm{x}$ & \\
\hline U1352C & $2 \mathrm{R}$ & $1 \mathrm{~W}$ & 12 & 574.7 & $\mathrm{x}$ & $\mathrm{x}$ & $\mathrm{x}$ & $\mathrm{x}$ & $\mathrm{x}$ & $\mathrm{x}$ & \\
\hline U1352C & $3 R$ & $1 \mathrm{~W}$ & 68 & 584.4 & $\mathrm{x}$ & $\mathrm{x}$ & $\mathrm{X}$ & $\mathrm{x}$ & $\mathrm{x}$ & $\mathrm{x}$ & \\
\hline U1352C & $9 \mathrm{R}$ & $1 \mathrm{~W}$ & 0 & 689.0 & $\mathrm{x}$ & $\mathrm{x}$ & $\mathrm{x}$ & $\mathrm{x}$ & $\mathrm{x}$ & $\mathrm{x}$ & $\mathrm{x}$ \\
\hline U1352C & $10 \mathrm{R}$ & $1 \mathrm{~W}$ & 50 & 698.7 & $\mathrm{x}$ & $\mathrm{x}$ & $\mathrm{x}$ & $\mathrm{x}$ & $\mathrm{x}$ & $\mathrm{x}$ & $\mathrm{x}$ \\
\hline U1352C & $14 R$ & $1 \mathrm{~W}$ & 100 & 737.5 & $\mathrm{x}$ & $\mathrm{x}$ & $\mathrm{x}$ & $\mathrm{X}$ & & $\mathrm{X}$ & $\mathrm{X}$ \\
\hline U1352C & $15 R$ & $1 \mathrm{~W}$ & 131 & 747.2 & $\mathrm{X}$ & $\mathrm{X}$ & $x$ & $\mathrm{X}$ & $\mathrm{X}$ & $x$ & $\mathrm{X}$ \\
\hline U1352C & $18 \mathrm{R}$ & $1 \mathrm{~W}$ & 19 & 776.3 & $\mathrm{X}$ & $\mathrm{X}$ & $\mathrm{X}$ & $\mathrm{x}$ & $\mathrm{X}$ & $x$ & \\
\hline U1352C & $21 \mathrm{R}$ & $2 \mathrm{~W}$ & 38 & 805.4 & $\mathrm{X}$ & $\mathrm{X}$ & X & $\mathrm{x}$ & $\mathrm{X}$ & $x$ & \\
\hline U1352C & $22 \mathrm{R}$ & $2 \mathrm{~W}$ & 33 & 815.0 & $\mathrm{X}$ & $\mathrm{X}$ & $\mathrm{X}$ & $\mathrm{x}$ & $\mathrm{x}$ & $\mathrm{x}$ & \\
\hline U1352C & $25 \mathrm{R}$ & CC & 0 & 843.8 & $\mathrm{X}$ & $\mathrm{X}$ & $\mathrm{X}$ & $x$ & $x$ & $\mathrm{X}$ & \\
\hline U1353B & $88 X$ & $1 \mathrm{~W}$ & $55-58$ & 509.6 & $x$ & $x$ & $x$ & $\mathrm{X}$ & $x$ & $\mathrm{x}$ & $\mathrm{X}$ \\
\hline U1353B & $92 X$ & CC & 8-12 & 547.1 & $\mathrm{X}$ & $\mathrm{X}$ & $\mathrm{X}$ & $\mathrm{X}$ & $\mathrm{X}$ & $x$ & $x$ \\
\hline U1354A & $15 \mathrm{H}$ & CC & 0 & 76.2 & $\mathrm{X}$ & X & X & $\mathrm{X}$ & $x$ & $x$ & $x$ \\
\hline U1354B & $13 \mathrm{H}$ & $2 \mathrm{~W}$ & 74 & 62.5 & X & $\mathrm{X}$ & $\mathrm{X}$ & $\mathrm{x}$ & $\mathrm{x}$ & $x$ & $x$ \\
\hline U1354C & $17 X$ & CC & 3 & 192.6 & $\mathrm{X}$ & $\mathrm{X}$ & $\mathrm{X}$ & $\mathrm{x}$ & $\mathrm{x}$ & $\mathrm{X}$ & $\mathrm{X}$ \\
\hline U1354C & $20 x$ & CC & 20 & 221.4 & $\mathrm{X}$ & $\mathrm{X}$ & $\mathrm{X}$ & $\mathrm{X}$ & $\mathrm{x}$ & & \\
\hline
\end{tabular}

* = sample was run, but no result was obtained. SEM = scanning electron microscope, EDS = X-ray spectroscopy mapping, XRD = X-ray diffraction. 
Table T2. Sample naming, porosity estimation, and bioclastic content.

\begin{tabular}{|c|c|c|c|c|c|c|c|c|c|}
\hline Hole & Core & Section & $\begin{array}{l}\text { Interval } \\
(\mathrm{cm})\end{array}$ & Burrow & $\begin{array}{l}\text { Porosity } \\
\text { (\%) }\end{array}$ & Pore type & Name & $\begin{array}{c}\text { Bioclasts } \\
\text { (undifferentiated) }\end{array}$ & Microfossils \\
\hline \multicolumn{10}{|l|}{$317-$} \\
\hline U1351B & $12 \mathrm{H}$ & $1 \mathrm{~W}$ & $115-116$ & NA & 25 & IEP: C, IAP: C & $\begin{array}{l}\text { Limestone (packed to poorly } \\
\text { washed biomicrite) }\end{array}$ & $\mathrm{C}$ & $\mathrm{C}$ \\
\hline U1351B & $19 X$ & $\mathrm{CC}$ & $25-27$ & NA & 20 & Moldic: C, IEP: T & Limestone (packed biomicrite) & $\mathrm{C}$ & $\mathrm{T}$ \\
\hline U1351B & $22 X$ & $\mathrm{CC}$ & $10-12$ & Burrowed & $<1$ & IAP: T & Sandy marlstone & $\mathrm{T}$ & $\mathrm{T}$ \\
\hline U1351B & $44 X$ & $1 \mathrm{~W}$ & $3-8$ & Bioturbated & $<1$ & None visible & Sandy marlstone & - & $\mathrm{T}$ \\
\hline U1351B & $46 X$ & $\mathrm{CC}$ & $1-5$ & Bioturbated & $<1$ & None visible & Marlstone & $\mathrm{T}$ & $\mathrm{T}$ \\
\hline U1351B & $96 X$ & $\mathrm{CC}$ & $5-8$ & NA & 20 & Moldic: C & Limestone (packed biomicrite) & $\mathrm{C}$ & $\mathrm{T}$ \\
\hline U1351B & $98 X$ & $\mathrm{CC}$ & $30-34$ & Bioturbated & 1 & Moldic: T & Sandy marlstone & $\mathrm{C}$ & $\mathrm{T}$ \\
\hline U1351B & $100 x$ & 3 & $15-17$ & Burrowed & 1 & Moldic: T & Marlstone & $\mathrm{T}$ & $\mathrm{C}$ \\
\hline U1351B & $102 X$ & $\mathrm{CC}$ & $4-8$ & Burrowed & $<1$ & Moldic: T & Marlstone & $\mathrm{T}$ & \\
\hline U1351B & $111 X$ & 1 & $4-7$ & Burrowed & 2 & Interparticle & Marlstone & $\mathrm{C}$ & $\mathrm{T}$ \\
\hline U1351B & $113 x$ & 2 & $131-135$ & Burrowed & 2 & Interparticle & Marlstone & $\mathrm{T}$ & - \\
\hline U1352B & $2 \mathrm{H}$ & $2 W$ & 32 & Burrowed & $<1$ & Interparticle & Marlstone (dolomicrite) & - & - \\
\hline U1352B & $42 X$ & $5 W$ & 5 & Bioturbated & 30 & IAP: C & Limestone (packed biomicrite) & $\mathrm{C}$ & $A$ \\
\hline U1352B & $52 X$ & $7 W$ & 4 & Burrowed & 15 & Moldic: C & Limestone (packed biomicrite) & $\mathrm{C}$ & $A$ \\
\hline U1352C & $2 \mathrm{R}$ & $1 \mathrm{~W}$ & 12 & Bioturbated & 25 & Moldic: C & Marlstone & $\mathrm{C}$ & $\mathrm{C}$ \\
\hline U1352C & $3 R$ & $1 \mathrm{~W}$ & 68 & Bioturbated & 15 & Moldic: C & Marlstone & $\mathrm{C}$ & $\mathrm{C}$ \\
\hline U1352C & $9 \mathrm{R}$ & $1 \mathrm{~W}$ & 0 & Burrowed & 1 & Moldic: T & Marlstone & $\mathrm{C}$ & - \\
\hline U1352C & $10 \mathrm{R}$ & $1 \mathrm{~W}$ & 50 & Burrowed & 10 & IAP: C, IEP: C & Marlstone & $\mathrm{T}$ & - \\
\hline U1352C & $14 \mathrm{R}$ & $1 \mathrm{~W}$ & 100 & Burrowed & 10 & $\begin{array}{l}\text { IAP primary: T, } \\
\text { IEP matrix: C }\end{array}$ & Marlstone & $\mathrm{T}$ & $\mathrm{C}$ \\
\hline U1352C & $15 R$ & $1 \mathrm{~W}$ & 131 & Burrowed & 15 & IEP matrix: C & Marlstone & $\mathrm{T}$ & $\mathrm{T}$ \\
\hline U1352C & $18 \mathrm{R}$ & $1 \mathrm{~W}$ & 19 & Burrowed & 1 & IEP matrix: C & Marlstone & $\mathrm{C}$ & $\mathrm{C}$ \\
\hline U1352C & $21 R$ & $2 W$ & 38 & Burrowed & & Moldic: C & Marlstone & $\mathrm{T}$ & $\mathrm{T}$ \\
\hline U1352C & $22 \mathrm{R}$ & $2 W$ & 33 & Burrowed & 1 & IEP matrix: T & Marlstone & $\mathrm{T}$ & $\mathrm{T}$ \\
\hline U1352C & $25 R$ & $\mathrm{CC}$ & 0 & Burrowed & 2 & IEP matrix: T & Marlstone & $\mathrm{T}$ & $\mathrm{T}$ \\
\hline U1353B & $88 \mathrm{X}$ & $1 \mathrm{~W}$ & $55-58$ & Bioturbated & $<1$ & IAP: T, Moldic: T & Sandy marlstone & $\mathrm{T}$ & $\mathrm{T}$ \\
\hline U1353B & $92 X$ & $\mathrm{CC}$ & $8-12$ & Burrowed & $<1$ & IAP: T & Sandy marlstone & $\mathrm{T}$ & - \\
\hline U1354A & $15 \mathrm{H}$ & $\mathrm{CC}$ & 0 & $\begin{array}{l}\text { Burrowed } \\
\text { bored hardground }\end{array}$ & $<1$ & Secondary borings & Marlstone (dolomicrite)? & - & - \\
\hline U1354B & $13 \mathrm{H}$ & $2 \mathrm{~W}$ & 74 & $\begin{array}{l}\text { Burrowed } \\
\text { bored hardground }\end{array}$ & $<1$ & Secondary borings & Marlstone (dolomicrite)? & - & - \\
\hline U1354C & $17 X$ & $\mathrm{CC}$ & 3 & Burrowed & $<1$ & IAP secondary & Sandy marlstone & $\mathrm{T}$ & \\
\hline U1354C & $20 x$ & $\mathrm{CC}$ & 20 & NA & 15 & $\begin{array}{l}\text { IAP primary: T, } \\
\text { Moldic: C }\end{array}$ & Limestone (packed biomicrite) & $\mathrm{C}$ & $\mathrm{C}$ \\
\hline
\end{tabular}

IEP $=$ interparticle, IAP $=$ intraparticle. $\mathrm{T}=$ trace $(<5 \%), C=$ common $(5 \%-30 \%), A=$ abundant $(>30 \%)$. 
Table T3. Thin section point count data. (Continued on next page.)

\begin{tabular}{|c|c|c|c|c|c|c|c|c|c|c|c|c|c|}
\hline \multirow[b]{2}{*}{ Hole } & \multirow[b]{2}{*}{ Core } & \multirow[b]{2}{*}{ Section } & \multirow[b]{2}{*}{$\begin{array}{l}\text { Interval } \\
(\mathrm{cm})\end{array}$} & \multicolumn{10}{|c|}{ Raw counts } \\
\hline & & & & $\begin{array}{l}\text { Quartz + } \\
\text { Feldspar }\end{array}$ & Mica & Bioclast & Matrix & $\begin{array}{l}\text { Micrite } \\
\text { cement }\end{array}$ & IAPC & IEPC & Porosity & Opaque & Total \\
\hline \multicolumn{14}{|l|}{$317-$} \\
\hline U1351B & $12 \mathrm{H}$ & $1 \mathrm{~W}$ & $115-116$ & 3 & & 143 & & & 19 & 53 & 66 & 16 & 300 \\
\hline U1351B & $19 x$ & $C C$ & $25-27$ & 36 & & 102 & 65 & 45 & 21 & & 31 & & 300 \\
\hline U1351B & $22 x$ & $\mathrm{CC}$ & $10-12$ & 136 & 11 & 7 & & & 2 & 139 & 2 & 3 & 300 \\
\hline U1351B & $44 X$ & $1 \mathrm{~W}$ & $3-8$ & 117 & 4 & 3 & 38 & 39 & & 93 & & 6 & 300 \\
\hline U1351B & $46 \mathrm{X}$ & $\mathrm{CC}$ & $1-5$ & 144 & 8 & 8 & 23 & 102 & & 15 & & & 300 \\
\hline U1351B & $96 \mathrm{X}$ & $\mathrm{CC}$ & $5-8$ & & & 87 & 17 & & 53 & 123 & 20 & & 300 \\
\hline U1351B & $98 \mathrm{x}$ & $\mathrm{CC}$ & $30-34$ & 132 & 18 & 19 & 16 & & 7 & 97 & 3 & 8 & 300 \\
\hline U1351B & $100 x$ & 3 & $15-17$ & 89 & & 14 & 45 & 94 & 8 & 45 & 5 & & 300 \\
\hline U1351B & $102 x$ & $\mathrm{CC}$ & $4-8$ & 96 & 23 & 4 & 42 & 132 & & & 3 & & 300 \\
\hline U1351B & $111 x$ & 1 & $4-7$ & 103 & 26 & 7 & 34 & 129 & & & 1 & & 300 \\
\hline U1351B & $113 x$ & 2 & $131-135$ & 92 & 5 & 5 & 33 & 125 & & 22 & 7 & 11 & 300 \\
\hline U1352B & $2 \mathrm{H}$ & $2 \mathrm{~W}$ & 32 & 78 & 21 & & 10 & 178 & & & 13 & & 300 \\
\hline U1352B & $42 \mathrm{X}$ & $5 W$ & 5 & & & 125 & 29 & 103 & 15 & & 28 & & 300 \\
\hline U1352B & $52 \mathrm{x}$ & $7 \mathrm{~W}$ & 4 & 21 & & 111 & 36 & 91 & 22 & & 19 & & 300 \\
\hline U1352C & $2 \mathrm{R}$ & $1 \mathrm{~W}$ & 12 & & & 109 & 29 & 121 & & & 35 & 6 & 300 \\
\hline U1352C & $3 R$ & $1 \mathrm{~W}$ & 68 & 34 & 14 & 27 & 44 & 164 & & & 11 & 6 & 300 \\
\hline U1352C & $9 \mathrm{R}$ & $1 \mathrm{~W}$ & 0 & 99 & 3 & 5 & 33 & 16 & & 134 & 1 & 9 & 300 \\
\hline U1352C & $10 \mathrm{R}$ & $1 \mathrm{~W}$ & 50 & 72 & 35 & & 155 & 28 & & & 10 & & 300 \\
\hline U1352C & $14 \mathrm{R}$ & $1 \mathrm{~W}$ & 100 & 65 & 24 & 18 & 158 & & & & 24 & 11 & 300 \\
\hline U1352C & $15 \mathrm{R}$ & $1 \mathrm{~W}$ & 131 & 87 & 10 & 12 & 106 & 42 & & & 31 & 12 & 300 \\
\hline U1352C & $18 \mathrm{R}$ & $1 \mathrm{~W}$ & 19 & 54 & 12 & 58 & 34 & 103 & 12 & 19 & 8 & & 300 \\
\hline U1352C & $21 R$ & $2 W$ & 38 & 73 & 17 & 22 & 43 & 101 & & 25 & 19 & & 300 \\
\hline U1352C & $22 \mathrm{R}$ & $2 W$ & 33 & 63 & 37 & 21 & 56 & 118 & & & 5 & & 300 \\
\hline U1352C & $25 \mathrm{R}$ & $\mathrm{CC}$ & 0 & 116 & 41 & 33 & 47 & 48 & & & 12 & 3 & 300 \\
\hline U1353B & $88 \mathrm{X}$ & $1 \mathrm{~W}$ & $55-58$ & 121 & 3 & 4 & 22 & 141 & & & & 9 & 300 \\
\hline U1353B & $92 X$ & CC & $8-12$ & 111 & 5 & 3 & 18 & 156 & & & & 7 & 300 \\
\hline U1354A & $15 \mathrm{H}$ & CC & 0 & 54 & & & 60 & 186 & & & & & 300 \\
\hline U1354B & $13 \mathrm{H}$ & $2 W$ & 74 & 73 & 8 & & 35 & 176 & & & & 8 & 300 \\
\hline U1354C & $17 X$ & CC & 3 & 98 & 2 & & 76 & 124 & & & & & 300 \\
\hline U1354C & $20 x$ & CC & 20 & & & 115 & 45 & 33 & 31 & 43 & 23 & 10 & 300 \\
\hline
\end{tabular}

Matrix $=($ detrital silt/clay sized material). IAPC $=$ intraparticle cement, IEPC $=$ interparticle cement. Normalized point counts $=100 \times$ point count $/$ 300. $\%$ Carb $=100 \times($ micrite cement + IAPC + IEPC $) / 300$. Terri $=$ terrigenous. 
Table T3. (continued).

\begin{tabular}{|c|c|c|c|c|c|c|c|c|c|c|c|c|c|c|}
\hline \multirow[b]{2}{*}{ Hole } & \multirow[b]{2}{*}{ Core } & \multirow[b]{2}{*}{ Section } & \multirow[b]{2}{*}{$\begin{array}{l}\text { Interval } \\
(\mathrm{cm})\end{array}$} & \multicolumn{10}{|c|}{ Normalized (\%) } & \multirow[b]{2}{*}{ Terri } \\
\hline & & & & $\begin{array}{l}\text { Quartz + } \\
\text { Feldspar }\end{array}$ & Mica & Bioclast & Matrix & $\begin{array}{l}\text { Micrite } \\
\text { cement }\end{array}$ & IAPC & IEPC & POR & Opaque & Carb & \\
\hline \multicolumn{15}{|l|}{$317-$} \\
\hline U1351B & $12 \mathrm{H}$ & $1 \mathrm{~W}$ & $115-116$ & 1.0 & 0 & 47.7 & 0 & 0 & 6.3 & 17.7 & 22.0 & 5.3 & 71.7 & 6.3 \\
\hline U1351B & $19 \mathrm{X}$ & $C C$ & $25-27$ & 12.0 & 0 & 34.0 & 21.7 & 15.0 & 7.0 & 0 & 10.3 & 0 & 56.0 & 33.7 \\
\hline U1351B & $22 x$ & CC & $10-12$ & 45.3 & 3.7 & 2.3 & 0 & 0 & 0.7 & 46.3 & 0.7 & 1.0 & 49.3 & 50 \\
\hline U1351B & $44 X$ & $1 \mathrm{~W}$ & $3-8$ & 39.0 & 1.3 & 1.0 & 12.7 & 13.0 & 0 & 31.0 & 0 & 2.0 & 45.0 & 55.0 \\
\hline U1351B & $46 x$ & CC & $1-5$ & 48.0 & 2.7 & 2.7 & 7.7 & 34.0 & 0 & 5.0 & 0 & 0 & 41.7 & 58.3 \\
\hline U1351B & $96 X$ & CC & $5-8$ & 0 & 0 & 29.0 & 5.7 & 0 & 17.7 & 41.0 & 6.7 & 0 & 87.7 & 5.7 \\
\hline U1351B & $98 \mathrm{X}$ & $\mathrm{CC}$ & $30-34$ & 44.0 & 6.0 & 6.3 & 5.3 & 0 & 2.3 & 32.3 & 1.0 & 2.7 & 41.0 & 58.0 \\
\hline U1351B & $100 x$ & 3 & $15-17$ & 29.7 & 0 & 4.7 & 15.0 & 31.3 & 2.7 & 15.0 & 1.7 & 0 & 53.7 & 44.7 \\
\hline U1351B & $102 X$ & $\mathrm{CC}$ & $4-8$ & 32.0 & 7.7 & 1.3 & 14.0 & 44.0 & 0 & 0 & 1.0 & 0 & 45.3 & 53.7 \\
\hline U1351B & $111 x$ & 1 & $4-7$ & 34.3 & 8.7 & 2.3 & 11.3 & 43.0 & 0 & 0 & 0.3 & 0 & 45.3 & 54.3 \\
\hline U1351B & $113 x$ & 2 & $131-135$ & 30.7 & 1.7 & 1.7 & 11.0 & 41.7 & 0 & 7.3 & 2.3 & 3.7 & 50.7 & 47.0 \\
\hline U1352B & $2 \mathrm{H}$ & $2 \mathrm{~W}$ & 32 & 26.0 & 7.0 & 0 & 3.3 & 59.3 & 0 & 0 & 4.3 & 0 & 59.3 & 36.3 \\
\hline U1352B & $42 \mathrm{X}$ & $5 \mathrm{~W}$ & 5 & 0 & 0 & 41.7 & 9.7 & 34.3 & 5.0 & 0 & 9.3 & 0 & 81.0 & 9.7 \\
\hline U1352B & $52 \mathrm{X}$ & $7 \mathrm{~W}$ & 4 & 7.0 & 0 & 37.0 & 12.0 & 30.3 & 7.3 & 0 & 6.3 & 0 & 74.7 & 19.0 \\
\hline U1352C & $2 \mathrm{R}$ & $1 \mathrm{~W}$ & 12 & 0 & 0 & 36.3 & 9.7 & 40.3 & 0 & 0 & 11.7 & 2.0 & 76.7 & 11.7 \\
\hline U1352C & $3 R$ & $1 \mathrm{~W}$ & 68 & 11.3 & 4.7 & 9.0 & 14.7 & 54.7 & 0 & 0 & 3.7 & 2.0 & 63.7 & 32.7 \\
\hline U1352C & $9 \mathrm{R}$ & $1 \mathrm{~W}$ & 0 & 33.0 & 1.0 & 1.7 & 11.0 & 5.3 & 0 & 44.7 & 0.3 & 3.0 & 51.7 & 48.0 \\
\hline U1352C & $10 \mathrm{R}$ & $1 \mathrm{~W}$ & 50 & 24.0 & 11.7 & 0 & 51.7 & 9.3 & 0 & 0 & 3.3 & 0 & 9.3 & 87.3 \\
\hline U1352C & $14 \mathrm{R}$ & $1 \mathrm{~W}$ & 100 & 21.7 & 8.0 & 6.0 & 52.7 & 0 & 0 & 0 & 8.0 & 3.7 & 6.0 & 86.0 \\
\hline U1352C & $15 \mathrm{R}$ & $1 \mathrm{~W}$ & 131 & 29.0 & 3.3 & 4.0 & 35.3 & 14.0 & 0 & 0 & 10.3 & 4.0 & 18.0 & 71.7 \\
\hline U1352C & $18 \mathrm{R}$ & $1 \mathrm{~W}$ & 19 & 18.0 & 4.0 & 19.3 & 11.3 & 34.3 & 4.0 & 6.3 & 2.7 & 0 & 64.0 & 33.3 \\
\hline U1352C & $21 \mathrm{R}$ & $2 \mathrm{~W}$ & 38 & 24.3 & 5.7 & 7.3 & 14.3 & 33.7 & 0 & 8.3 & 6.3 & 0 & 49.3 & 44.3 \\
\hline U1352C & $22 \mathrm{R}$ & $2 W$ & 33 & 21.0 & 12.3 & 7.0 & 18.7 & 39.3 & 0 & 0 & 1.7 & 0 & 46.3 & 52.0 \\
\hline U1352C & $25 \mathrm{R}$ & $C C$ & 0 & 38.7 & 13.7 & 11.0 & 15.7 & 16.0 & 0 & 0 & 4.0 & 1.0 & 27.0 & 69.0 \\
\hline U1353B & $88 \mathrm{X}$ & $1 \mathrm{~W}$ & $55-58$ & 40.3 & 1.0 & 1.3 & 7.3 & 47.0 & 0 & 0 & 0 & 3.0 & 48.3 & 51.7 \\
\hline U1353B & $92 X$ & $C C$ & $8-12$ & 37.0 & 1.7 & 1.0 & 6.0 & 52.0 & 0 & 0 & 0 & 2.3 & 53.0 & 47.0 \\
\hline U1354A & $15 \mathrm{H}$ & $\mathrm{CC}$ & 0 & 18.0 & 0 & 0 & 20 & 62.0 & 0 & 0 & 0 & 0 & 62.0 & 38.0 \\
\hline U1354B & $13 \mathrm{H}$ & $2 W$ & 74 & 24.3 & 2.7 & 0 & 11.7 & 58.7 & 0 & 0 & 0 & 2.7 & 58.7 & 41.3 \\
\hline U1354C & $17 X$ & $\mathrm{CC}$ & 3 & 32.7 & 0.7 & 0 & 25.3 & 41.3 & 0 & 0 & 0 & 0 & 41.3 & 58.7 \\
\hline U1354C & $20 x$ & $\mathrm{CC}$ & 20 & 0 & 0 & 38.3 & 15.0 & 11.0 & 10.3 & 14.3 & 7.7 & 3.3 & 74.0 & 18.3 \\
\hline
\end{tabular}


Table T4. XRD analysis for quartz and identified carbonate phases.

\begin{tabular}{|c|c|c|c|c|c|c|c|c|c|}
\hline Hole & Core & Section & $\begin{array}{l}\text { Interval } \\
(\mathrm{cm})\end{array}$ & $\begin{array}{l}\text { Aragonite } \\
\quad(\mathrm{cps})\end{array}$ & $\begin{array}{l}\text { Quartz } \\
\text { (cps) }\end{array}$ & $\begin{array}{c}\text { Calcite } \\
\text { (cps) }\end{array}$ & $\begin{array}{l}\text { Mg calcite } \\
\quad(\mathrm{cps})\end{array}$ & $\begin{array}{l}\text { Ankerite } \\
(\mathrm{cps})\end{array}$ & $\begin{array}{l}\text { Ferroan } \\
\text { dolomite } \\
\quad(c p s)\end{array}$ \\
\hline \multicolumn{10}{|l|}{$317-$} \\
\hline U1351B & $12 \mathrm{H}$ & $1 \mathrm{~W}$ & $115-116$ & 6 & 109 & 864 & - & - & 1 \\
\hline U1351B & $19 x$ & $\mathrm{CC}$ & $25-27$ & 7 & 65 & 813 & - & - & 5 \\
\hline U1351B & $22 X$ & $\mathrm{CC}$ & $10-12$ & - & 642 & 914 & - & - & - \\
\hline U1351B & $44 X$ & $1 \mathrm{~W}$ & $3-8$ & 2 & 353 & 512 & - & - & 6 \\
\hline U1351B & $46 x$ & $\mathrm{CC}$ & $1-5$ & - & 515 & 675 & - & - & 41 \\
\hline U1351B & $96 x$ & $\mathrm{CC}$ & $5-8$ & 4 & 685 & 515 & 4 & - & - \\
\hline U1351B & $98 X$ & $\mathrm{CC}$ & $30-34$ & No sample & No sample & No sample & No sample & No sample & No sample \\
\hline U1351B & $100 x$ & 3 & $15-17$ & 1 & 708 & 737 & - & - & 31 \\
\hline U1351B & $102 X$ & $\mathrm{CC}$ & $4-8$ & - & 467 & 440 & 1 & - & - \\
\hline U1351B & $111 x$ & 1 & $4-7$ & 3 & 544 & 654 & - & - & - \\
\hline U1351B & $113 x$ & 2 & $131-135$ & 1 & 460 & 684 & 2 & - & 5 \\
\hline U1352B & $2 \mathrm{H}$ & $2 W$ & 32 & - & 542 & 4 & 1 & - & 331 \\
\hline U1352B & $42 X$ & $5 W$ & 5 & 2 & 227 & 549 & - & - & - \\
\hline U1352B & $52 X$ & $7 W$ & 4 & 3 & 282 & 698 & - & - & 22 \\
\hline U1352C & $2 \mathrm{R}$ & $1 \mathrm{~W}$ & 12 & 1 & 288 & 1090 & - & - & 6 \\
\hline U1352C & $3 R$ & $1 \mathrm{~W}$ & 68 & 3 & 192 & 700 & - & - & 1 \\
\hline U1352C & $9 \mathrm{R}$ & $1 \mathrm{~W}$ & 0 & 1 & 240 & 406 & - & - & 27 \\
\hline U1352C & $10 \mathrm{R}$ & $1 \mathrm{~W}$ & 50 & 1 & 383 & 146 & 1 & 68 & 71 \\
\hline U1352C & $14 \mathrm{R}$ & $1 \mathrm{~W}$ & 100 & 10 & 619 & 339 & - & - & 18 \\
\hline U1352C & $15 R$ & $1 \mathrm{~W}$ & 131 & - & 363 & 442 & - & - & 18 \\
\hline U1352C & $18 \mathrm{R}$ & $1 \mathrm{~W}$ & 19 & - & 357 & 705 & - & - & 10 \\
\hline U1352C & $21 \mathrm{R}$ & $2 W$ & 38 & - & 387 & 418 & - & - & 13 \\
\hline U1352C & $22 \mathrm{R}$ & $2 W$ & 33 & 2 & 334 & 414 & - & - & 82 \\
\hline U1352C & $25 R$ & $\mathrm{CC}$ & 0 & - & 378 & 340 & - & - & 5 \\
\hline U1353B & $88 X$ & $1 \mathrm{~W}$ & $55-58$ & - & 392 & - & 164 & - & - \\
\hline U1353B & $92 x$ & $\mathrm{CC}$ & $8-12$ & - & 885 & - & 144 & - & 5 \\
\hline U1354A & $15 \mathrm{H}$ & $\mathrm{CC}$ & 0 & - & 282 & - & - & - & 421 \\
\hline U1354B & $13 \mathrm{H}$ & $2 W$ & 74 & - & 175 & - & - & 212 & 316 \\
\hline U1354C & $17 X$ & $\mathrm{CC}$ & 3 & - & 1430 & 322 & - & - & - \\
\hline U1354C & $20 x$ & $\mathrm{CC}$ & 20 & No sample & No sample & No sample & No sample & No sample & No sample \\
\hline
\end{tabular}


Table T5. SEM-EDS elemental analysis of predominant carbonate cement phases.

\begin{tabular}{|c|c|c|c|c|c|c|c|c|c|c|c|c|c|}
\hline \multirow[b]{2}{*}{ Hole } & \multirow[b]{2}{*}{ Core } & \multirow[b]{2}{*}{ Section } & \multirow{2}{*}{$\begin{array}{l}\text { Interval } \\
(\mathrm{cm})\end{array}$} & \multicolumn{8}{|c|}{ Major elements (cps) } & \multirow[b]{2}{*}{$\mathrm{Ca} / \mathrm{Mg}$} & \multirow[b]{2}{*}{$\mathrm{Mg} / \mathrm{Fe}$} \\
\hline & & & & $\mathrm{Na}$ & $\mathrm{Mg}$ & $\mathrm{Al}$ & $\mathrm{Si}$ & $\mathrm{K}$ & $\mathrm{Ca}$ & $\mathrm{Fe}$ & $\mathrm{Mn}$ & & \\
\hline \multicolumn{14}{|l|}{$317-$} \\
\hline U1351B & $12 \mathrm{H}$ & $1 \mathrm{~W}$ & $115-116$ & - & 45.8 & 41.7 & 94.9 & - & 1206.9 & 12.3 & - & 27.0 & 3.7 \\
\hline U1351B & $19 x$ & $\mathrm{CC}$ & $25-27$ & & & & & & & & & & \\
\hline U1351B & $22 x$ & $\mathrm{CC}$ & $10-12$ & 47.8 & 58.3 & 112.0 & 359.3 & 39.5 & 1711.6 & 23.9 & - & 29.4 & 2.4 \\
\hline U1351B & $44 X$ & $1 \mathrm{~W}$ & $3-8$ & 35.7 & 48.8 & 126.0 & 450.8 & 39.4 & 994.8 & 20.4 & - & 20.7 & 2.5 \\
\hline U1351B & $46 \mathrm{X}$ & $\mathrm{CC}$ & $1-5$ & 0.0 & 77.1 & 0.0 & & & & & & & \\
\hline U1351B & $96 \mathrm{X}$ & $\mathrm{CC}$ & $5-8$ & & & & & & & & & & \\
\hline U1351B & $98 \mathrm{x}$ & $\mathrm{CC}$ & $30-34$ & 39.2 & 54.1 & 103.6 & 341.8 & 41.7 & 1634.4 & 26.2 & - & 30.3 & 2.2 \\
\hline U1351B & $100 x$ & 3 & $15-17$ & 41.4 & 51.0 & 89.4 & 343.9 & - & 1624.3 & 33.7 & - & 31.9 & 1.5 \\
\hline U1351B & $102 x$ & CC & $4-8$ & 45.3 & 52.5 & 109.1 & 338.6 & 36.8 & 1609.4 & 23.7 & - & 31.3 & 2.3 \\
\hline U1351B & $111 x$ & 1 & $4-7$ & 38.7 & 49.7 & 97.7 & 313.7 & 37.9 & 1604.9 & 22.1 & - & 32.3 & 2.3 \\
\hline U1351B & $113 x$ & 2 & $131-135$ & 35.3 & 51.6 & 69.0 & 195.3 & - & 1756.9 & 21.0 & - & 35.0 & 2.5 \\
\hline U1352B & $2 \mathrm{H}$ & $2 \mathrm{~W}$ & 32 & 49.8 & 558.2 & 135.7 & 416.2 & 43.5 & 807.7 & 25.0 & - & 1.4 & 22.9 \\
\hline U1352B & $42 X$ & $5 W$ & 5 & 25.7 & 38.5 & 49.4 & 138.0 & - & 901.0 & - & - & 23.5 & - \\
\hline U1352B & $52 x$ & $7 \mathrm{~W}$ & 4 & 26.2 & 53.8 & 55.1 & 134.7 & 24.7 & 1263.1 & 17.6 & - & 23.6 & 3.1 \\
\hline U1352B & $52 X$ & $7 \mathrm{~W}$ & 4 & - & 356.8 & 57.2 & 140.3 & - & 891.9 & - & - & 2.5 & - \\
\hline U1352C & $2 \mathrm{R}$ & $1 \mathrm{~W}$ & 12 & 26.6 & 43.1 & 64.0 & 150.1 & - & 1230.0 & 12.8 & - & 28.6 & 3.6 \\
\hline U1352C & $3 R$ & $1 \mathrm{~W}$ & 68 & 25.9 & 43.3 & 52.3 & 133.5 & 23.0 & 1221.2 & 9.9 & - & 29.3 & 4.4 \\
\hline U1352C & $9 \mathrm{R}$ & $1 \mathrm{~W}$ & 0 & 32.8 & 42.1 & 76.0 & 268.9 & 24.5 & 1184.7 & 12.5 & - & 28.2 & 3.4 \\
\hline U1352C & $10 \mathrm{R}$ & $1 \mathrm{~W}$ & 50 & 46.9 & 375.6 & 150.9 & 348.6 & 59.0 & 743.7 & 38.0 & - & 2.0 & 9.9 \\
\hline U1352C & $14 \mathrm{R}$ & $1 \mathrm{~W}$ & 100 & & & & & & & & & & \\
\hline U1352C & $15 \mathrm{R}$ & $1 \mathrm{~W}$ & 131 & 27.0 & 48.5 & 76.0 & 249.6 & 27.8 & 1072.9 & 13.3 & - & 22.1 & 3.9 \\
\hline U1352C & $15 \mathrm{R}$ & $1 \mathrm{~W}$ & 131 & - & 297.2 & 147.8 & 864.6 & - & 475.0 & - & - & 1.7 & - \\
\hline U1352C & $18 \mathrm{R}$ & $1 \mathrm{~W}$ & 19 & 28.6 & 36.5 & 65.5 & 186.6 & 24.1 & 1182.8 & 12.5 & - & 32.7 & 2.9 \\
\hline U1352C & $21 \mathrm{R}$ & $2 \mathrm{~W}$ & 38 & 25.3 & 34.8 & 64.6 & 173.1 & 24.2 & 783.6 & 13.1 & - & 23.9 & 2.7 \\
\hline U1352C & $21 R$ & $2 W$ & 38 & 23.9 & 274.2 & 94.6 & 247.7 & 32.1 & 534.4 & - & - & 2.0 & - \\
\hline U1352C & $22 \mathrm{R}$ & $2 \mathrm{~W}$ & 33 & 21.0 & 29.3 & 62.2 & 186.7 & 21.4 & 763.3 & 11.2 & - & 26.1 & 2.6 \\
\hline U1352C & $25 \mathrm{R}$ & $C C$ & 0 & 19.2 & 30.8 & 58.3 & 179.1 & 19.3 & 648.1 & 10.1 & - & 21.1 & 3.1 \\
\hline U1353B & $88 \mathrm{X}$ & $1 \mathrm{~W}$ & $55-58$ & 38.7 & 192.2 & 127.8 & 444.3 & 49.4 & 1410.4 & 21.9 & - & 7.3 & 8.9 \\
\hline U1353B & $92 x$ & $\mathrm{CC}$ & $8-12$ & 35.8 & 154.2 & 78.3 & 301.7 & 31.5 & 1561.0 & 13.2 & - & 10.1 & 11.7 \\
\hline U1354A & $15 \mathrm{H}$ & $C C$ & 0 & 50.4 & 524.3 & 190.4 & 490.6 & 71.4 & 791.0 & 42.0 & - & 1.5 & 12.8 \\
\hline U1354B & $13 \mathrm{H}$ & $2 \mathrm{~W}$ & 74 & 45.3 & 519.7 & 154.7 & 387.6 & 58.0 & 903.7 & 51.3 & - & 1.7 & 11.0 \\
\hline U1354C & $17 X$ & $C C$ & 3 & 54.6 & 83.9 & 225.3 & 718.9 & 65.2 & 1068.9 & 26.0 & - & 12.8 & 3.2 \\
\hline U1354C & $20 x$ & CC & 20 & - & 56.5 & 73.4 & 112.0 & - & 1691.7 & 18.0 & - & 30.2 & 3.2 \\
\hline \multicolumn{14}{|c|}{ Rhombohedral crystals } \\
\hline U1352B & $52 x$ & $7 \mathrm{~W}$ & 4 & - & 356.8 & 57.2 & 140.3 & - & 891.9 & - & & 2.5 & - \\
\hline U1352C & $15 \mathrm{R}$ & $1 \mathrm{~W}$ & 131 & - & 297.2 & 147.8 & 864.6 & - & 475.0 & - & & 1.7 & - \\
\hline U1352C & $21 \mathrm{R}$ & $2 \mathrm{~W}$ & 38 & 23.9 & 274.2 & 94.6 & 247.7 & 32.1 & 534.4 & - & & 2.0 & - \\
\hline
\end{tabular}


Table T6. Results of stable isotope analysis.

\begin{tabular}{|c|c|c|c|c|c|c|c|c|c|}
\hline Hole & Core & Section & $\begin{array}{l}\text { Interval } \\
(\mathrm{cm})\end{array}$ & $\begin{array}{c}\delta^{13} C \text { VPDB } \\
(\% o)\end{array}$ & $\begin{array}{l}\text { Standard } \\
\text { deviation }\end{array}$ & $\begin{array}{c}\delta^{18} \mathrm{O} \text { VPDB } \\
(\% \mathrm{o})\end{array}$ & $\begin{array}{l}\text { Standard } \\
\text { deviation }\end{array}$ & $\begin{array}{c}\delta^{18} \text { O SMOW } \\
(\% o)\end{array}$ & $\begin{array}{l}\text { Standard } \\
\text { deviation }\end{array}$ \\
\hline \multicolumn{10}{|l|}{$317-$} \\
\hline U1351B & $22 x$ & $\mathrm{CC}$ & $10-12$ & 1.33 & 0.21 & -2.69 & 0.35 & 28.13 & 0.37 \\
\hline U1351B & $44 X$ & $1 \mathrm{~W}$ & $3-8$ & 2.32 & 0.11 & 0.02 & 0.08 & 30.93 & 0.08 \\
\hline U1351B & $46 X$ & $\mathrm{CC}$ & $1-5$ & No signal & & No signal & & No signal & \\
\hline U1351B & $102 x$ & $\mathrm{CC}$ & $4-8$ & 0.49 & 0.05 & -2.07 & 0.09 & 28.77 & 0.09 \\
\hline U1351B & $102 x$ & $\mathrm{CC}$ & $4-8$ & 0.46 & 0.09 & -1.98 & 0.05 & 28.86 & 0.05 \\
\hline U1351B & $113 x$ & 2 & $131-135$ & 0.46 & 0.06 & -1.99 & 0.06 & 28.86 & 0.06 \\
\hline U1352B & $2 \mathrm{H}$ & $2 W$ & 32 & -20.39 & 0.05 & 6.66 & 0.04 & 37.78 & 0.04 \\
\hline U1352C & $9 \mathrm{R}$ & $1 \mathrm{~W}$ & 0 & 0.55 & 0.09 & -0.05 & 0.12 & 30.85 & 0.12 \\
\hline U1352C & $10 \mathrm{R}$ & $1 \mathrm{~W}$ & 50 & 2.83 & 0.08 & 1.92 & 0.05 & 32.89 & 0.05 \\
\hline U1352C & $14 \mathrm{R}$ & $1 \mathrm{~W}$ & 100 & 0.62 & 0.10 & 1.02 & 0.17 & 31.96 & 0.18 \\
\hline U1352C & $15 R$ & $1 \mathrm{~W}$ & 131 & 0.57 & 0.04 & 0.93 & 0.05 & 31.87 & 0.05 \\
\hline U1353B & $88 \mathrm{X}$ & & $55-58$ & -39.14 & 0.07 & 2.26 & 0.04 & 33.24 & 0.04 \\
\hline U1353B & $88 \mathrm{X}$ & & $55-58$ & -39.22 & 0.03 & 2.65 & 0.08 & 33.64 & 0.08 \\
\hline U1353B & $92 X$ & $\mathrm{CC}$ & $8-12$ & -56.82 & 0.10 & 2.88 & 0.19 & 33.87 & 0.20 \\
\hline U1354A & $15 \mathrm{H}$ & $\mathrm{CC}$ & 0 & -19.37 & 0.03 & 6.42 & 0.11 & 37.53 & 0.11 \\
\hline U1354B & $13 \mathrm{H}$ & $2 W$ & 74 & -13.52 & 0.06 & 5.83 & 0.04 & 36.91 & 0.04 \\
\hline U1354C & $17 X$ & $\mathrm{CC}$ & 3 & -7.85 & 0.05 & 1.75 & 0.03 & 32.71 & 0.03 \\
\hline U1354C & $17 X$ & $\mathrm{CC}$ & 3 & -7.72 & 0.05 & 1.78 & 0.06 & 32.74 & 0.06 \\
\hline \multicolumn{10}{|l|}{ Standard } \\
\hline Std A & & & & -39.75 & 0.04 & -19.15 & 0.05 & & \\
\hline NBS-18 & & & & -5.01 & 0.03 & -23.2 & 0.03 & & \\
\hline NBS-19 & & & & 1.95 & 0.03 & -2.2 & 0.04 & & \\
\hline
\end{tabular}

VPDB = Vienna Peedee belemnite, SMOW = standard mean ocean water. 